\title{
Reviews
}

\section{Property Degradation of Tetragonal Zirconia Induced by Low-Temperature Defect Reaction with Water Molecules}

\author{
Xin Guo \\ Elektrokeramische Materialien, Institut für Festkörperforschung, Forschungszentrum J ülich, \\ 52425 J ülich, Germany
}

Received April 6, 2004. Revised Manuscript Received J une 23, 2004

\begin{abstract}
Tetragonal $\mathrm{ZrO}_{2}$ exhibits good ionic conductivity, high strength, and fracture toughness. But while annealing at relatively low temperatures $\left(63-400^{\circ} \mathrm{C}\right)$, tetragonal $\mathrm{ZrO}_{2}$ spontaneously transforms to a monoclinic one, and its electrical and mechanical properties degrade severely. The phenomenological observations of the low-temperature degradation of tetragonal $\mathrm{ZrO}_{2}$ are summarized, and major degradation mechanisms are critically reviewed. It is crucial to maintain sufficient oxygen vacancy concentration to stabilize the tetragonal structure; excess reduction of the oxygen vacancy concentration causes the tetragonal to monoclinic transformation. Water molecules can be incorporated into the $\mathrm{ZrO}_{2}$ lattice by filling oxygen vacancies, which leads to the formation of proton defects. Experimental and theoretical evidence support such a defect reaction between oxygen vacancies and water molecules. And a degradation mechanism based on this defect reaction satisfactorily explains all the phenomenological observations. The diffusion rate of oxygen vacancies at low temperatures is not high enough to cause the observed degradation depth; therefore, the relatively fast diffusion of proton defects most probably controls the degradation process.
\end{abstract}

\section{Introduction}

In 1975, Garvie, Hannink, and Pascoe ${ }^{1}$ first reported the high strength and excellent fracture toughness of tetragonal $\mathrm{ZrO}_{2}$. Later, it is established that the high strength (e.g., $2000 \mathrm{MPa}$ ) and toughness (e.g., 12 $\mathrm{MPa} \cdot \mathrm{m}^{1 / 2}$ ) are attributed to the stress-induced martensitic phase transformation of tetragonal phase to a monoclinic one in the vicinity of crack fronts. ${ }^{2-4} \mathrm{~F}$ or the first time a ceramic material attains the fracture toughness comparable to steel at room temperature. Tetragonal $\mathrm{ZrO}_{2}$ has also good ionic conductivity; its conductivity is higher than that of cubic $\mathrm{ZrO}_{2}$ at temperatures $<700{ }^{\circ} \mathrm{C} .{ }^{5}$ However, there exists a major drawback for tetragonal $\mathrm{ZrO}_{2}$ ceramic: tetragonal $\mathrm{ZrO}_{2}$ undergoes a spontaneous tetragonal to monodinic transformation in the presence of water or water vapor when anneal ed at relatively low temperatures $\left(63-400{ }^{\circ} \mathrm{C}\right)$, engendering cracks in the transformed surface due to the volume expansion accompanying the phase transformation, thereby severely degrading the electrical and mechanical properties. ${ }^{6-110}$ This phenomenon is called "low-temperature degradation of tetragonal $\mathrm{ZrO}_{2}$ ". The catastrophic consequence is shown in Figure 1 in which a tetragonal $\mathrm{ZrO}_{2}$ sample crumbled to small debris after annealing in 26 mbar water vapor at $250^{\circ} \mathrm{C}$ for 30 days.

†Tel: +49-2461-616147. Fax: +49-2461-612550. E-mails: x.guo@fzjuelich.de; guo@ WE.RWTH-Aachen.de.
It is striking that a ceramic pellet disintegrated to isolated grains (Figure 1c).

The first report of the low-temperature degradation of tetragonal $\mathrm{ZrO}_{2}$ was made by Kobayashi, Kuwajima, and Masaki ${ }^{6}$ in 1981. Since then, much research has been performed on the degradation and majority of the works are given in refs 7-110 in chronological order. The degradation has not yet been fully understood, although many degradation mechanisms have been proposed. In this article the advantages and disadvantages of typical degradation mechanisms are elaborated, with an objective of determining the most appropriate degradation mechanism.

\section{Phenomenological Observations of the Degradation}

Although the works on the low-temperature degradation are not totally in accord with each other, the foll owing features of the degradation have been generally accepted:

(1) The tetragonal to monoclinic transformation proceeds from the surface to the interior ${ }^{6-110}$ A diffusion process controls the transformation as indicated in Figure 2. The volume expansion accompanying the phase transformation cracks $\mathrm{ZrO}_{2}$ samples, and the cracking is intergranular (see, e.g., Figure 1c). 10,49,90,109

(2) The degradation occurs at relatively low temperatures (e.g., $63-400{ }^{\circ} \mathrm{C}^{10,14,24,27-29,34,36,41,45,52,53,56,61,84}$ ), 

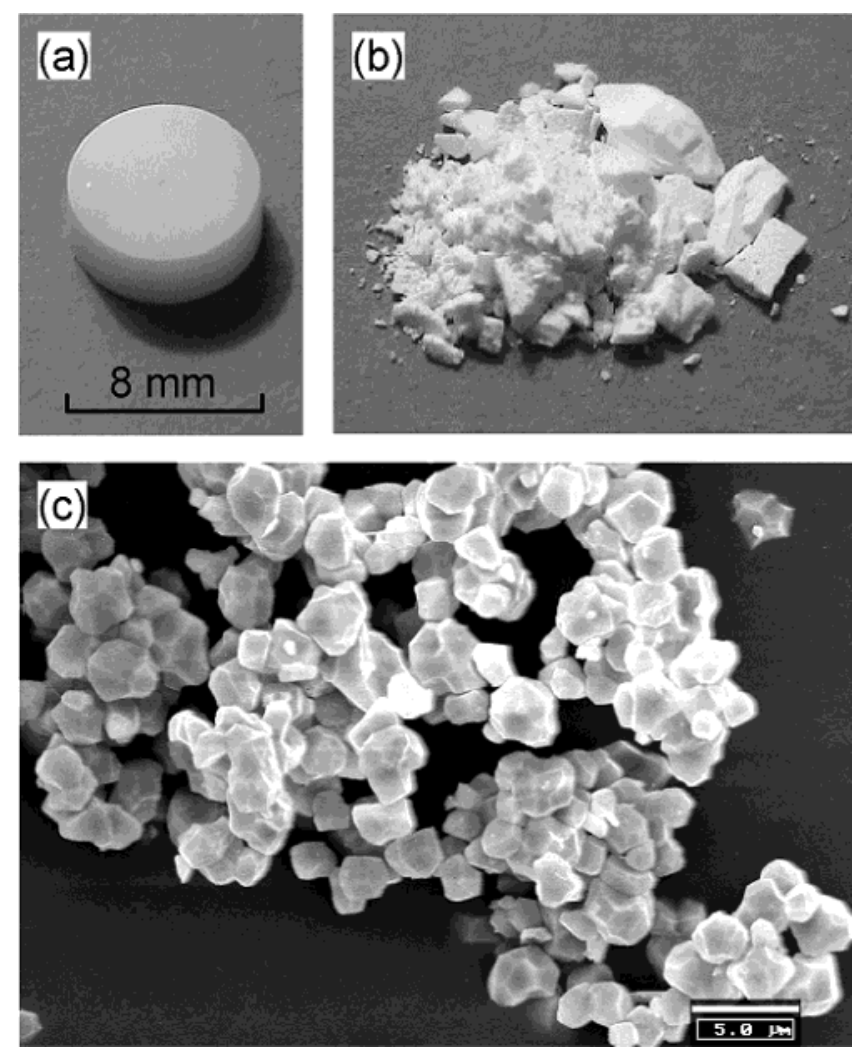

Figure 1. $3 \mathrm{~mol} \% \mathrm{Y}_{2} \mathrm{O}_{3}$-doped $\mathrm{ZrO}_{2}$ ceramic sample at different stages: (a) as-sintered, (b) after annealing in 26 mbar water vapor at $250{ }^{\circ} \mathrm{C}$ for 30 days, and (c) scanning electron micrograph of fractured debris.

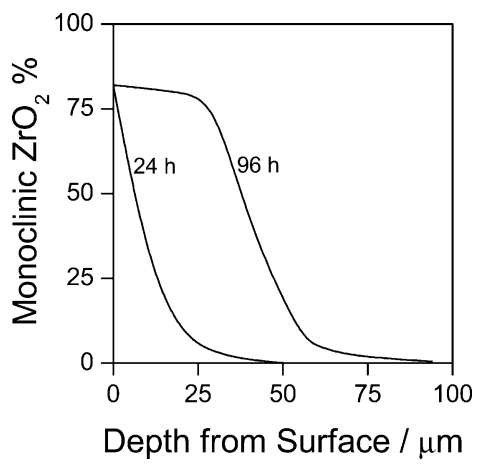

Figure 2. Transformation depth profile in $2 \mathrm{~mol} \% \mathrm{Y}_{2} \mathrm{O}_{3-}$ doped $\mathrm{ZrO}_{2}$ after annealing at $300{ }^{\circ} \mathrm{C}$ in air for 24 and $96 \mathrm{~h}$, respectively (after lio et al. ${ }^{22}$ ).

and at temperatures around $250^{\circ} \mathrm{C}$ the degradation is most pronounced. $8,19,23,27-29,50,56,57$

(3) Of all the major constituents of air, only water vapor causes the tetragonal to monoclinic transformation. 7,18,22,65 The degradation rate increases with increasing water vapor pressure, ${ }^{24}$ and the degradation becomes much more severe in the presence of water. $11,17,21,24,29,34,61,62,71$ The acidic or basic addition in aqueous solution does not have a noticeable influence on the formation of monoclinic $\mathrm{ZrO}_{2}{ }^{10,11}$

(4) The degradation is more marked in the case of lower dopant content (see, e.g., Figure 3).13,14,19-21,23,27,29,34,79

(5) Decreasing grain size retards the degradation. $9,13,14,18,19,21,23,25,27-30,34,61,102,108,110$ When the tetragonal grain size is below a critical value, the degradation is significantly retarded. The critical grain size is dopant level dependent; e.g., the critical grain size increases

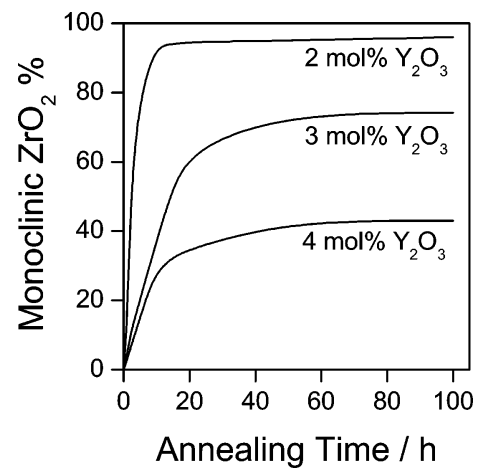

Figure 3. Time dependence of monoclinic $\mathrm{ZrO}_{2}$ percentage in the surface layers of 2, 3, and $4 \mathrm{~mol} \% \mathrm{Y}_{2} \mathrm{O}_{3}$-doped $\mathrm{ZrO}_{2}$ samples while annealed at $200{ }^{\circ} \mathrm{C}$ in 15.4 mbar water vapor (after Sato et al. ${ }^{24}$ ).

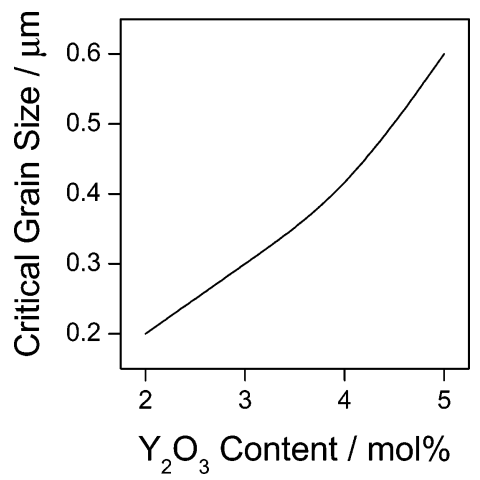

Figure 4. Critical tetragonal grain size as a function of $\mathrm{Y}_{2} \mathrm{O}_{3}$ content (after Watanabe et al. ${ }^{9}$ ). The samples with an average grain size below the critical grain size did not show any sign of degradation after annealing at $300{ }^{\circ} \mathrm{C}$ in air for $1000 \mathrm{~h}$.

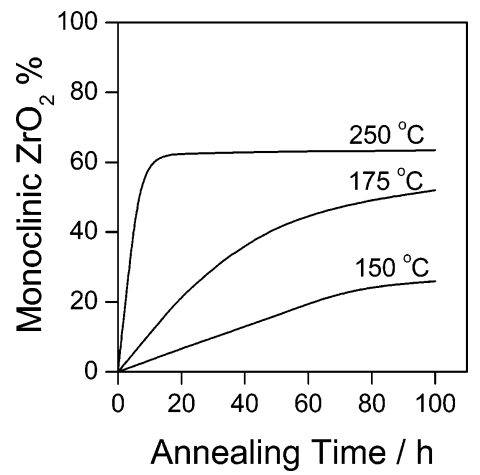

Figure 5. Time dependence of monoclinic $\mathrm{ZrO}_{2}$ percentage in the surface layers of $3 \mathrm{~mol} \% \mathrm{Y}_{2} \mathrm{O}_{3}$-doped $\mathrm{ZrO}_{2}$ samples while annealed in air at 150,175 , and $250^{\circ} \mathrm{C}$, respectively (after Sato et al. ${ }^{14}$ ).

from 0.2 to $0.6 \mu \mathrm{m}$ if the $\mathrm{Y}_{2} \mathrm{O}_{3}$ concentration increases from 2 to $5 \mathrm{~mol} \%$ (Figure 4).

(6) The amount of monoclinic phase increases with annealing time and reaches saturation after annealing for a sufficiently long time (see, e.g., Figure 5). 10,13,14,18,24

(7) Under certain circumstances the degraded properties can be recovered by annealing at high temperatures in a vacuum or dry atmosphere, ${ }^{15,27}$ and the annealing retransforms the monoclinic phase back to the tetragonal phase. ${ }^{57,65,92}$

A viable mechanism should be able to explain the effects of dopant content and grain size and the phe nomena of monoclinic phase saturation and retransformation. 


\section{Some Typical Degradation Mechanisms}

Many attempts have been taken to explain the degradation; some typical mechanisms are summarized as follows:

Mechanism by Lange et al. ${ }^{18} \alpha-Y(O H)_{3}$ crystallites (20-50 nm in diameter) were observed in the $6.6 \mathrm{~mol}$ $\% \mathrm{Y}_{2} \mathrm{O}_{3}$-doped $\mathrm{ZrO}_{2}$ thin foil with transmission electron microscopy (TEM) after annealing at $250{ }^{\circ} \mathrm{C}$ in a water vapor environment for $18 \mathrm{~h}$. Therefore, Lange et al. suggested that water vapor reacted with $\mathrm{Y}_{2} \mathrm{O}_{3}$ to form the crystal lites and the reaction locally drew $\mathrm{Y}_{2} \mathrm{O}_{3}$ from tetragonal grains, transforming the tetragonal grains to monoclinic ones. Winnubst and Burggraaf, ${ }^{21}$ Azzoni et al., ${ }^{44}$ and Li et al. ${ }^{62}$ supported this mechanism. This mechanism naturally explains the effect of dopant content, and it also explains the effect of critical grain size. Lange et al. ${ }^{18}$ pointed out, "as a monoclinic nucleus grows by further diffusion of yttrium, it will achieve a critical size where it can spontaneously grow without further yttrium diffusion to completely transform the tetragonal grain in which it was growing." If the transformed grain is large enough, microcracking will occur, which provides a path for water to penetrate to another grain, allowing the process to repeat. If the transformed grain is smaller than the critical size required for microcracking, then subsequent transformation will be limited by the long-range diffusion of yttrium ions to the surface. The retransformation can be explained by this mechanism as well. At temperatures higher than $1000^{\circ} \mathrm{C}$ the $\alpha-Y(O H)_{3}$ crystallites may react with $\mathrm{ZrO}_{2}$ and yttrium is redissolved in the grains, which results in a retransformation back to the tetragonal structure. But this mechanism cannot explain the phenomenon of monoclinic phase saturation. In addition, it faces a major challenge: it requires short-range diffusion of yttrium. Yoshimura et al. ${ }^{27}$ estimated the diffusion time of yttrium ions over a distance of only 1 $\mathrm{nm}$ at $250^{\circ} \mathrm{C}$, which is about $10^{29} \mathrm{~s}$. It is very unlikely that the $\alpha-Y(O H)_{3}$ crystallites could be formed by the diffusion of yttrium at $250{ }^{\circ} \mathrm{C}$ within only $18 \mathrm{~h}$. And the dissolution of yttrium ions in water has also been disproved by the analysis of the solvent. ${ }^{11,26,27,92}$

Mechanism by Sato and Shimada.11 Water plays an important role in the low-temperature degradation. Therefore, Sato and Shimada proposed the stress corrosion by water; i.e., water reacts with $\mathrm{Zr}-\mathrm{O}-\mathrm{Zr}$ bonds at crack tips and $\mathrm{Zr}-\mathrm{OH}$ bonds are formed, i.e., $-\mathrm{Zr}-$ $\mathrm{O}-\mathrm{Zr}-+\mathrm{H}_{2} \mathrm{O} \rightarrow-\mathrm{Zr}-\mathrm{OH}+\mathrm{HO}-\mathrm{Zr}-$. This reaction results in a release of the surface energy that acts to stabilize the tetragonal phase and the growth of preexisting surface flaws; consequently, the transformation to monoclinic phase proceeds. The compounds with a similar chemical structure to water, e.g., those nonaqueous solvents with a molecular structure containing a lone pair el ectron orbital opposite a proton donor site, al so accel erates the degradation. ${ }^{11}$ This mechanism can explain the phenomenon of retransformation. However, Sato and Shimada did not give evidence for the formation of $\mathrm{Zr}-\mathrm{OH}$ bonds, and how the bond formation causes the release of the surface energy was not explained and proved. More adversely, this mechanism cannot explain the effects of dopant content and grain size and the phenomenon of monoclinic phase saturation.
Table 1. Lattice Parameters of Monoclinic $\mathrm{ZrO}_{2}$ Transformed from Tetragonal Phase after Different Treatments ${ }^{27}$

\begin{tabular}{cccccc}
\hline treatment & $\mathrm{a}(\mathrm{nm})$ & $\mathrm{b}(\mathrm{nm})$ & $\mathrm{c}(\mathrm{nm})$ & $\beta(\mathrm{deg})$ & $\mathrm{V}\left(\mathrm{nm}^{3}\right)$ \\
\hline$(1)^{\mathrm{a}}$ & 0.5165 & 0.5254 & 0.5258 & 98.51 & 0.1411 \\
$(2)^{\mathrm{b}}$ & 0.5174 & 0.5252 & 0.5275 & 99.06 & 0.1415 \\
$(3)^{\mathrm{c}}$ & 0.5169 & 0.5253 & 0.5266 & 98.89 & 0.1413
\end{tabular}

a Mechanical grinding. ${ }^{b}$ Annealing in water at $250{ }^{\circ} \mathrm{C}$ under $100 \mathrm{MPa}$ for $6 \mathrm{~h}$. ${ }^{\mathrm{C}}$ Reheating in a vacuum at $400{ }^{\circ} \mathrm{C}$ for $6 \mathrm{~h}$.

Mechanism by Yoshimura et al. 27,29 Yoshimura et al. demonstrated the introduction of hydroxyl ions $\mathrm{OH}^{-}$ by low-temperature annealing and the exclusi on of $\mathrm{OH}^{-}$ by reheating in a vacuum or at high temperatures, with subsequent volume change (Table 1 ) and about 0.233 wt $\%$ weight variation. Therefore, they proposed the following degradation mechanism: first step, chemical adsorption of $\mathrm{H}_{2} \mathrm{O}$ on the surface; second step, formation of $\mathrm{Zr}-\mathrm{OH}$ and/or $\mathrm{Y}-\mathrm{OH}$ bonds, which brings about the lattice strain on the surface; third step, strain accumulation by the diffusion of $\mathrm{OH}^{-}$on the surface and in the lattice; fourth step, the accumulated strain area acts as a nucleus of monoclinic phase in the tetragonal matrix. However, one crucial point of this mechanism, how the formation of $\mathrm{Zr}-\mathrm{OH}$ and/or $\mathrm{Y}-\mathrm{OH}$ bonds brings about the lattice strain on the surface and in the bulk, was not explained and proved. This mechanism can explain the effect of dopant content by suggesting the formation of $\mathrm{Y}-\mathrm{OH}$ bonds and it can also explain the phenomenon of retransformation, but it cannot explain the effect of grain size and the phenomenon of monoclinic phase saturation.

Mechanism by Hernandez et al. ${ }^{36} \mathrm{Hernandez}$ et al. detected hydroxyl ions $\mathrm{OH}^{-}$and possibly the formation of $\mathrm{Y}-\mathrm{OH}$ bonds by means of $\mathrm{X}$-ray photoelectron spectroscopy (XPS). On this basis, they proposed that the degradation occurs by the following steps: (i) adsorption and dissociation of water molecules on the surface, (ii) reaction of $\mathrm{OH}^{-}$in the more active points $\left(\mathrm{Y}_{2} \mathrm{O}_{3}\right)$ to form an oxyhydroxide $\mathrm{YO}(\mathrm{OH})$ species that is stable under hydrothermal conditions, (iii) formation of purely tetragonal $\mathrm{ZrO}_{2}$ embryos which are coherent in the tetragonal matrix, (iv) growth of the embryos to above a critical size and then the tetragonal to monoclinic transformation. It is unclear from ref 36 whether the formation and the growth of purely tetragonal $\mathrm{ZrO}_{2}$ embryos require the diffusion of cations at low temperatures or not. This mechanism can explain the effect of dopant content by suggesting the formation of $\mathrm{YO}(\mathrm{OH})$ species; it can also explain the phenomenon of retransformation but it cannot explain the effect of grain size and the phenomenon of monoclinic phase saturation.

Mechanism by $\mathrm{Kim}$ et al. ${ }^{45} \mathrm{Kim}$ et al. detected hydroxyl ions $\mathrm{OH}^{-}$after annealing $3 \mathrm{~mol} \% \mathrm{Y}_{2} \mathrm{O}_{3}$-doped $\mathrm{ZrO}_{2}$ in water and $\mathrm{LiOH}$ solution at 90, 150, and 200 ${ }^{\circ} \mathrm{C}$. They proposed the following mechanism for the degradation in an aqueous solution: $\mathrm{OH}^{-}$ions diffuse through oxygen vacancies and interact with the vacancies to form $\mathrm{Zr}-\mathrm{OH}$ bonds, which contributes to the tensile strain around the occupied vacancy sites. The buildup of the tensile strain ends up with the onset of the tetragonal to monoclinic transformation. Oxygen vacancies are the most active defects in acceptor-doped $\mathrm{ZrO}_{2}$. The merit of this mechanism is that it realizes the importance of oxygen vacancies in the low-temper- 
ature degradation. But XPS investigations $30,36,62$ indicate the formation of $\mathrm{Y}-\mathrm{OH}$ bonds, instead of $\mathrm{Zr}-\mathrm{OH}$ bonds. Yet it is unclear from this mechanism how the tensile strain strong enough to cause the tetragonal to monoclinic transformation is built up. This mechanism can explain the phenomenon of retransformation, but it cannot explain the effects of dopant content and grain size and the phenomenon of monoclinic phase saturation.

\section{Point Defects and Low-Temperature Degradation}

4.1. Degradation Mechanism Based on Point Defect Reaction. Livage et al. ${ }^{111}$ suggested that oxygen vacancies play an important role in the stabilization of $\mathrm{ZrO}_{2}$. A simulation ${ }^{112}$ based on a self-consistent tightbinding model showed that the stabilization of the tetragonal and the cubic structure could be achieved by doping $\mathrm{ZrO}_{2}$ crystals with oxygen vacancies only. Oxygen vacancies are created in the $\mathrm{ZrO}_{2}$ lattice by doping with acceptors, e.g., trivalent oxide $\mathrm{Y}_{2} \mathrm{O}_{3}$; however, doping with donors, e.g., pentavalent oxide $\mathrm{Nb}_{2} \mathrm{O}_{5}$, annihilates oxygen vacancies due to the charge compensation $\mathrm{Y}^{3+} / \mathrm{N} \mathrm{b}^{5+}$ related to the host $\mathrm{Zr}^{4+}$. By creating and anni hilating oxygen vacancies in $\mathrm{ZrO}_{2}$, Kountouros and Petzow ${ }^{40}$ actually proved that there are a critical minimum and a critical maximum oxygen vacancy concentration for the cubic, the tetragonal, and the monoclinic phase, respectively; excess oxygen vacancy concentration variation results in phase transformation. For example, the cubic phase of $8 \mathrm{~mol} \% \mathrm{Y}_{2} \mathrm{O}_{3}$-doped $\mathrm{ZrO}_{2}$ was transformed to tetragonal phase by further doping with $6 \mathrm{~mol} \% \mathrm{Nb}_{2} \mathrm{O}_{5} ; 0$ in this case the effective acceptor concentration was equival ent to $2 \mathrm{~mol} \% \mathrm{Y}_{2} \mathrm{O}_{3}$.

In many oxides, oxygen vacancies can be filled by water molecules according to

$$
\mathrm{H}_{2} \mathrm{O}+\mathrm{V}_{\mathrm{O}}^{\ddot{2}}+\mathrm{O}_{\mathrm{O}}^{\times} \rightarrow 2(\mathrm{OH})_{\mathrm{O}}^{\circ}
$$

where $(\mathrm{OH})_{\mathrm{O}}^{\circ}$ is a proton defect. This reaction is the basis for the proton conduction in, e.g., $\mathrm{SrTiO}_{3}, \mathrm{SrZrO}_{3}$, $\mathrm{BaCeO}_{3}$, and $\mathrm{Y}_{2} \mathrm{O}_{3} .{ }^{113-115}$ Based on this reaction, another mechanism for the low-temperature degradation of tetragonal $\mathrm{ZrO}_{2}$ has evolved, ${ }^{72,73,86,89,90,107,109}$ which consists of the following steps: (i) chemical adsorption of $\mathrm{H}_{2} \mathrm{O}$ on the $\mathrm{ZrO}_{2}$ surface, (ii) reaction of $\mathrm{H}_{2} \mathrm{O}$ with $\mathrm{O}^{2-}$ on the $\mathrm{ZrO}_{2}$ surface to form hydroxyl ions $\mathrm{OH}^{-}$, (iii) penetration of $\mathrm{OH}^{-}$into the inner part by grain boundary diffusion, (vi) filling of oxygen vacancies by $\mathrm{OH}^{-}$ ions, and therefore the formation of proton defects, and (v) occurrence of a tetragonal to monoclinic transformation when the oxygen vacancy concentration is reduced to the extent that the tetragonal phase is no longer stable. If the amount of the phase transformation is large enough, due to the volume expansion associated with the phase transformation, both micro- and macrocracks can be produced in the transformed surface layer, and the cracks open up new surfaces to react with water or water vapor, leading to further spontaneous transformation. As indicated in Figure 2, a diffusion process controls the transformation. This mechanism requires only the diffusion of proton defects.

4.2. Experimental and Theoretical Evidence. Formation and Diffusion of Hydroxyl Ions. Many theo-

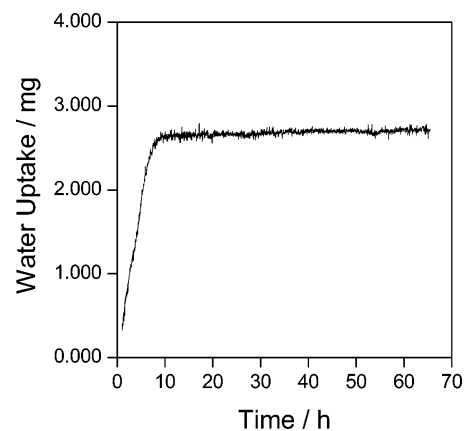

Figure 6. Water uptake in $3 \mathrm{~mol} \% \mathrm{Y}_{2} \mathrm{O}_{3}$-doped $\mathrm{ZrO}_{2}$ during annealing in 1 bar water vapor at $250{ }^{\circ} \mathrm{C}$ (after Guo and Schober ${ }^{109}$ ).

retical and experimental results support this mechanism. F or example, an atomic simulation ${ }^{116}$ discloses the dissociative adsorption of water on the tetragonal $\mathrm{ZrO}_{2}$ surface. And hydroxyl ions $\left(\mathrm{OH}^{-}\right)$were detected on the tetragonal $\mathrm{ZrO}_{2}$ surface by $\mathrm{X}$-ray photoelectron spectroscopy (XPS) 30,36,62,73 and infrared adsorption spectroscopy. ${ }^{27,30,45}$ A Fourier transform infrared (FT-IR) transmission spectrometry investigation ${ }^{70}$ proved that $\mathrm{H}$ species penetrated the $\mathrm{ZrO}_{2}$ bulk after annealing in water. $\mathrm{Higher} \mathrm{OH}^{-}$concentration was detected by XPS at the grain boundaries of $3 \mathrm{~mol} \% \mathrm{Y}_{2} \mathrm{O}_{3}$-doped tetragonal $\mathrm{ZrO}_{2}$ after annealing in boiling water for $40 \mathrm{~h}, 73$ suggesting that $\mathrm{OH}^{-}$ions intergranularly diffused into the interior of the sample during annealing. In addition, it was found that the thickness of the degraded layer was strongly related to the diffusion distance of $\mathrm{OH}^{-} .45$ If estimated from Figure 2, the diffusion coefficient of $(\mathrm{OH})_{0}^{\circ}$ in $2 \mathrm{~mol} \% \mathrm{Y}_{2} \mathrm{O}_{3}$-doped $\mathrm{ZrO}_{2}$ at $300{ }^{\circ} \mathrm{C}$ is about 3 $\times 10^{-10} \mathrm{~cm}^{2} \mathrm{~s}^{-1}$, comparable with that in $\mathrm{SrTiO}_{3}$ (about $10^{-9} \mathrm{~cm}^{2} \mathrm{~s}^{-1}$ at $\left.300^{\circ} \mathrm{C}^{114,115}\right)$. But it is much higher than the diffusion coefficient of oxygen vacancies (about $2 \times$ $10^{-14} \mathrm{~cm}^{2} \mathrm{~s}^{-1}$ in $14.2 \mathrm{~mol} \% \mathrm{CaO}$-doped $\mathrm{ZrO}_{2}$ at $300^{\circ} \mathrm{C}$, extrapolated from data between 800 and $1097{ }^{\circ} \mathrm{C}^{117}$ ), suggesting that the diffusion of oxygen vacancies may not be important to the degradation.

Water Incorporation. According to the degradation mechanism based on eq 1 , steps (i) - (vi) should result in the incorporation of water molecules into tetragonal $\mathrm{ZrO}_{2}$. As demonstrated in Figure 6, water was indeed incorporated into $3 \mathrm{~mol} \% \mathrm{Y}_{2} \mathrm{O}_{3}$-doped $\mathrm{ZrO}_{2}$ during annealing in 1 bar water vapor at $250{ }^{\circ} \mathrm{C} .{ }^{109} \mathrm{As}$ shown in Figure 6, the water uptake continuously increased within the first $\sim 8 \mathrm{~h}$ and then leveled off (or saturated) at $\sim 2.5 \mathrm{mg}$, corresponding to an incorporation of $\sim 1.5$ mol $\% \mathrm{H}_{2} \mathrm{O}$ or $\sim 3.0 \mathrm{~mol} \%(\mathrm{OH})_{\mathrm{O}}^{\circ}$. A fast process, e.g., grain boundary diffusion, likely accomplished the water incorporation. The phase of the sample was initially totally tetragonal, but after the water incorporation $\sim 73 \%$ of the phase became monoclinic. It is noted that the oxygen vacancy concentration in $3 \mathrm{~mol} \% \mathrm{Y}_{2} \mathrm{O}_{3}-$ doped $\mathrm{ZrO}_{2}$ is $3 \mathrm{~mol} \%$. According to eq 1, 50\% of the oxygen vacancies in the sample could be filled by the incorporation of $\sim 1.5 \mathrm{~mol} \% \mathrm{H}_{2} \mathrm{O}$; the oxygen vacancy concentration in the sample was then lower than the critical minimum concentration for tetragonal phase (1.7 mol $\%^{40}$ ). Under this condition, the tetragonal phase transformed to the monoclinic one. The incorporation of water molecules into the tetragonal $\mathrm{ZrO}_{2}$ lattice should cause the lattice expansion; such a lattice expansion was al so observed. ${ }^{109}$ Y oshimura et al. ${ }^{27}$ found that 
the volume of the monoclinic structure transformed from the tetragonal phase by annealing in water is larger than that by mechanical grinding (Table 1 ). This lattice expansion was attributed to the incorporation of $\mathrm{OH}^{-}$ ions.

Filling of Oxygen Vacancies by Water Molecules. Under the condition that oxygen vacancies are totally filled by water molecules, $\left[(\mathrm{OH})_{\mathrm{O}}^{\circ}\right] /\left[\mathrm{V}_{\mathrm{O}}^{\circ}\right]$ is expected to be 2 according to eq 1 . Here $\left[(\mathrm{OH})_{\mathrm{O}}^{\circ}\right]$ is the concentration of the proton defects and [ $\left.\mathrm{V}_{\mathrm{o}}^{*}\right]$ the initial oxygen vacancy concentration. Kruse et al. ${ }^{43}$ anneal ed $3 \mathrm{~mol} \%$ $\mathrm{Y}_{2} \mathrm{O}_{3}$-doped $\mathrm{ZrO}_{2}$ ceramic samples at $200{ }^{\circ} \mathrm{C}$ in $\mathrm{D}_{2} \mathrm{O}$ enriched water vapor with a vapor pressure of $15 \mathrm{bar}$ for $2 \mathrm{~h}$; afterward, they determined the concentration of hydrogen and deuterium by means of elastic recoil detection analysis (ERDA). After the hydrothermal treatment, the combined concentration of hydrogen and deuterium $([\mathrm{H}]+[\mathrm{D}])$ was about $1.4 \times 10^{21} \mathrm{~cm}^{-3}$, whereas the oxygen vacancy concentration, $\left[\mathrm{V}_{0}^{*}\right]$, in 3 mol $\% \mathrm{Y}_{2} \mathrm{O}_{3}$-doped $\mathrm{ZrO}_{2}$ is about $4.33 \times 10^{20} \mathrm{~cm}^{-3}$. Then $([\mathrm{H}]+[\mathrm{D}]) /\left[\mathrm{V}_{\mathrm{o}}\right] \approx 3$, comparing with the expected ratio of 2. Within experimental error the agreement is quite good.

Proton Conduction. The expected proton conduction was also checked. Water vapor concentration cells,

$$
\text { (+) } \mathrm{p}_{\mathrm{H}_{2} \mathrm{O}}^{\prime}, \mathrm{Ag} / \mathrm{ZrO}_{2} / \mathrm{Ag}, \mathrm{p}_{\mathrm{H}_{2} \mathrm{O}}^{\prime \prime}(-)
$$

where one side of a slab of $3 \mathrm{~mol} \% \mathrm{Y}_{2} \mathrm{O}_{3}$-doped $\mathrm{ZrO}_{2}$ coated with silver electrodes was exposed to water vapor pressures $\mathrm{p}_{\mathrm{H}_{2} \mathrm{O}}$ of 30-50 mbar while the other side was constantly held at a $\mathrm{p}_{\mathrm{H}_{2} \mathrm{O}}$ of 6.1 mbar, were constructed, and the polarity and the Nernst vol tage of the cells was checked at $250{ }^{\circ} \mathrm{C} .109$ The polarity of the observed voltages agreed in all cases with the expected proton conduction. However, there was no cl ear-cut correl ation between the magnitude of the observed Nernst vol tages and the partial pressures involved as dictated by Nernst's equation. This failure to yield the expected Nernst voltages is ascribed to the fact that local equilibria were not established near the electrodes. The observed correct polarity, however, is a clear indication that we were dealing with proton conduction in the experiments.

As the mobility of proton defects $(\mathrm{OH})_{\mathrm{O}}^{\circ}$ is higher, ${ }^{113-115}$ it is predicted that the electrical conductivity of the sample should increase by the introduction of proton defects. Attempts 86,90 have been taken to measure the electrical conductivity of $3 \mathrm{~mol} \% \mathrm{Y}_{2} \mathrm{O}_{3}-$ doped tetragonal $\mathrm{ZrO}_{2}$ while being annealed in water vapor. However, the tetragonal to monoclinic phase transformation and the sample cracking severely affected the sample electrical conductivity; therefore, it is not possible to establish an unambiguous correlation between the conductivity and the proton conduction. However, such a correlation was obtained for $8 \mathrm{~mol} \%$ $\mathrm{Y}_{2} \mathrm{O}_{3}$-doped cubic $\mathrm{ZrO}_{2} \cdot{ }^{107}$ Cubic $\mathrm{ZrO}_{2}$ has al ways been presumed to be stable in the environment known to cause the degradation to tetragonal $\mathrm{ZrO}_{2}$. Neverthel ess, none of the all above mechanisms prohibits a similar degradation of cubic phase to tetragonal, even to a monoclinic one. For example, the formation of hydroxyl ions on the cubic $\mathrm{ZrO}_{2}$ surface was also observed by XPS. ${ }^{89}$ Recently, similar degradation was al so observed

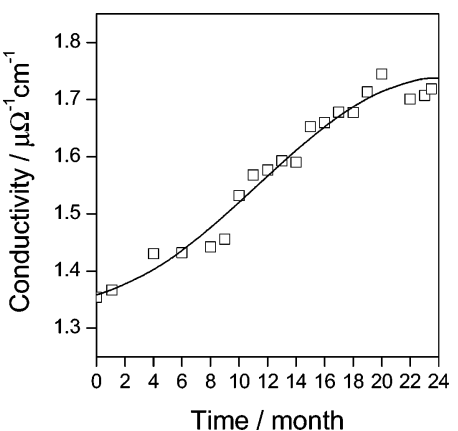

Figure 7. Bulk electrical conductivity of $8 \mathrm{~mol}_{\%} \mathrm{Y}_{2} \mathrm{O}_{3}$-doped $\mathrm{ZrO}_{2}$ versus annealing time at $250{ }^{\circ} \mathrm{C}$ in 26 mbar water vapor (after Guo and $\mathrm{He}^{107}$ ).

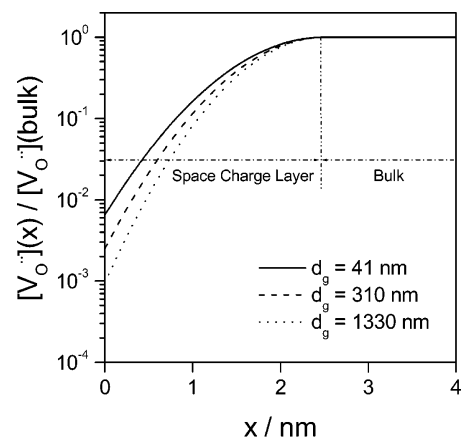

Figure 8. Oxygen vacancy profiles in the space charge layers of $3 \mathrm{~mol} \% \mathrm{Y}_{2} \mathrm{O}_{3}$-doped $\mathrm{ZrO}_{2}$ samples with different grain sizes $\left(d_{g}\right)$ at $550{ }^{\circ} \mathrm{C}$ (after Guo and Zhang ${ }^{124}$ ). In this figure, $x$ is the distance from the grain boundary, $\left[\mathrm{V}_{\mathrm{O}}^{* 0}\right](\mathrm{x})$ is the oxygen vacancy concentration at $\mathrm{x}$, and $\left[\mathrm{V}_{\mathrm{O}}^{\circ}\right]$ (bulk) the oxygen vacancy concentration in the bulk.

for cubic $\mathrm{ZrO}_{2}$ (sample cracking and precipitation of monoclinic phase) after annealing in water vapor at 250 ${ }^{\circ} \mathrm{C}$ for 2 years. ${ }^{107}$ Unlike tetragonal samples, the degradation only produced a few cracks in the cubic $\mathrm{ZrO}_{2}$ sample, which makes reliable el ectrical measurements possible. The bulk el ectrical conductivity measured by impedance spectroscopy is shown in Figure 7. It has been demonstrated that impedance spectroscopy is an effective technique to monitor in situ the low-temperature degradati on. $86,88,90,108,110$ As shown in this figure, the bulk conductivity continuously increased with anneal ing time; about 30\% increase was measured, which is attributed to the expected proton conduction. The possibility of proton conduction in $\mathrm{ZrO}_{2}$ has also been evaluated in refs 118 and 119, in which the experimental evidence supports proton conduction in $\mathrm{ZrO}_{2}$ in the presence of water vapor. Especially in monoclinic $\mathrm{ZrO}_{2}$, proton defects can be significant, while not dominant. 118

4.3. Explanation of Phenomenological Observations. The degradation mechanism based on eq 1 explains the effects of dopant content and grain size and the phenomena of monoclinic phase saturation and retransformation. In the case of high dopant content, more oxygen vacancies should be filled to induce the degradation. The grain boundaries of acceptor-doped $\mathrm{ZrO}_{2}$ are characterized by a positive grain boundary potential and subsequent depletion of oxygen vacancies in the adjacent space charge layers (Figure 8).120-124 Such a feature makes the grain boundaries vul nerable to the $\mathrm{OH}^{-}$attack, which may explain the intergranular cracking. As demonstrated previously, ${ }^{123,124}$ the oxygen vacancy concentration in the space charge layer in- 
creases with decreasing grain size (Figure 8). Therefore, more oxygen vacancies in the space charge layer should be filled to induce the degradation at the grain boundaries in the case of finer grain size. Figure 6 is very similar to the plot for $250{ }^{\circ} \mathrm{C}$ given in Figure 5 , suggesting that the saturation shown in Figure 5 is likely due to the saturation of water incorporation (defined by temperature and water vapor pressure). When heated in a vacuum or to high temperatures, the incorporated proton defects escape from the $\mathrm{ZrO}_{2}$ lattice, as indicated by the lattice shrinkage shown in Table 1. As a result, reaction 1 is reversed, and then the tetragonal to monodinic transformation is reversed accordingly.

The majority of the works on the degradation deal with $\mathrm{Y}_{2} \mathrm{O}_{3}$-doped $\mathrm{ZrO}_{2}$. However, the modification of the defect structure in $\mathrm{ZrO}_{2}$ by doping with oxides other than $\mathrm{Y}_{2} \mathrm{O}_{3}$, e.g., $\mathrm{MgO}$, is expected to change the degradation behavior. It has been reported that the degradation of $\mathrm{ZrO}_{2}$ is retarded by the doping of $\mathrm{MgO} .12,20,33,41$ Owing to the double charges, magnesium ions ( $\mathrm{Mg}_{z \mathrm{r}}^{\prime \prime}$ ) strongly bind oxygen vacancies $\left(\mathrm{V}_{\mathrm{o}}^{\circ}\right)$, which is evident from the low conductivity of $\mathrm{MgO}$-doped $\mathrm{ZrO}_{2}{ }^{125}$ and the very large binding energy of $\left(\mathrm{Mg}_{z \mathrm{r}}^{\prime \prime} \mathrm{V}_{\mathrm{o}}^{\circ}\right)^{\times}(-146 \mathrm{~kJ} / \mathrm{mol}$,

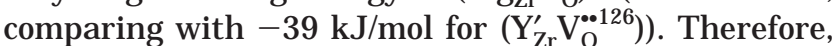
the filling of oxygen vacancies by water molecules (eq 1) becomes more difficult; as a result, the degradation of $\mathrm{MgO}$-doped $\mathrm{ZrO}_{2}$ is retarded. The similar effect of $\mathrm{CaO}^{20}$ can be similarly explained.

XPS investigations of degraded $\mathrm{Y}_{2} \mathrm{O}_{3}$-doped tetragonal $\mathrm{ZrO}_{2}$ samples suggested the formation of $\mathrm{Y}-\mathrm{OH}$ bonds. ${ }^{36,62}$ The mechanism based on eq 1 is favorable to the formation of the $\mathrm{Y}-\mathrm{OH}$ bond because the reaction between proton defects $\left((\mathrm{OH})_{\mathrm{O}}^{\circ}\right)$ and yttrium ions $\left(\mathrm{Y}_{\mathrm{Zr}}^{\prime}\right)$ is energetically favorable as a result of the opposite charges of the defects. This al so hel ps in explaining the formation of $\mathrm{Y}(\mathrm{OH})_{3}$ crystallites.

\section{Concluding Remarks}

Similar to the electrical properties, the low-temperature degradation of tetragonal $\mathrm{ZrO}_{2}$ is dominated by its defect structure. A degradation mechanism based on the point defect reaction between oxygen vacancies and water molecules is developed, which consists of the following steps: (i) chemical adsorption of $\mathrm{H}_{2} \mathrm{O}$ on the $\mathrm{ZrO}_{2}$ surface, (ii) reaction of $\mathrm{H}_{2} \mathrm{O}$ with $\mathrm{O}^{2-}$ on the $\mathrm{ZrO}_{2}$ surface to form hydroxyl ions $\mathrm{OH}^{-}$, (iii) penetration of the hydroxyl ions into the inner part by grain boundary diffusion, (vi) filling of oxygen vacancies by the hydroxyl ions, and therefore the formation of proton defects, and (v) occurrence of a tetragonal to monoclinic transformation when the oxygen vacancy concentration is reduced to the extent that the tetragonal phase is no longer stable. The tetragonal to monoclinic transformation may be martensitic, as the martensitic transformation is known under certain circumstances to occur isothermally. ${ }^{127}$ This mechanism requires only the diffusion of proton defects at low temperatures, which is a few orders of magnitude higher than that of oxygen vacancies. Comparing with the other ones, this mechanism is soundly supported by theoretical and experimental evidence, and it explains all the phenomenological observations of the low-temperature degradation.
The low-temperature degradation can be retarded by applying one of the following strategies: (1) increase of dopant concentration; (2) reduction of grain size; (3) introduction of inert materials, e.g., $\mathrm{CeO}_{2}, 17,20,36,48,52,56,68,101$ $\mathrm{TiO}_{2},{ }^{20,54} \mathrm{Al}_{2} \mathrm{O}_{3}, 13,20,35,52,58,63,75,88,93,99,106 \mathrm{CuO}, 67,81,100$ or carbon;105 (4) formation of an inert surface layer, e.g., a recrystallized tetragonal layer with finer grain size, 32 or a cubic surface layer, ${ }^{66}$ or a silica encapsulating surface layer. ${ }^{82}$

\section{References}

(1) Garvie, R. C.; Hannink, R. H.; Pascoe, R. T. Nature 1975, 258 703.

(2) Gupta, T. K.; Lange, F. F.; Bechtold, J . H. J . Mater. Sci. 1978, 13,1464

(3) Porter, D. L.; Evans, A. G.; Heuer, A. H. Acta Metall. 1979, 27, 1649.

(4) Evans, A. G.; Burlingame, N.; Drory, M.; Kriven, W. M. Acta Metall. 1981, 29, 447.

(5) Weppner, W. Solid Sate I onics 1992, 52, 15

(6) Kobayashi, K.; Kuwajima, H.; Masaki, T. Solid Statel onics 1981 $3 / 4,489$

(7) Murase, Y.; Kato, E. J . Am. Ceram. Soc. 1983, 66, 196.

(8) Sato, T.; Shimada, M. J . Am. Ceram. Soc. 1984, 67, C-212.

(9) Watanabe, M.; Iio, S.; Fukuura, I. In Science and Technol ogy of Zirconia II; Claussen, N., Rühle, M., Heuer, A. H., Eds.; American Ceramic Society: Columbus, $\mathrm{OH}, 1984$; p 391.

(10) Nakajima, K.; Kobayashi, K.; Murata, Y. In Science and Technol ogy of Zirconia II: Claussen, N., Rühle, M., Heuer, A. H., Eds. American Ceramic Society: Columbus, OH, 1984; p 399.

(11) Sato, T.; Shimada, M. J . Am. Ceram. Soc. 1985, 68, 356.

(12) Swain, M. V. J . Mater. Sci. Lett. 1985, 4, 848.

(13) Tsukama, K.; Shimada, M. J . Mater. Sci. Lett. 1985, 4, 857

(14) Sato, T.; Ohtaki, S.; Shimada, M. J . Mater. Sci. 1985, 20, 1466

(15) Matsumoto, R. L. K. J . Am. Ceram. Soc. 1985, 68, C-213.

(16) Sato, T.; Ohtaki, S.; Endo, T.; Schimada, M. J . Am. Ceram. Soc. 1985, 68, C-320.

(17) Sato, T.; Shimada, M. Am. Ceram. Soc. Bull. 1985, 64, 1382.

(18) Lange, F. F.; Dunlop, G. L.; Davis, B. I. J . Am. Ceram. Soc. 1986, 69, 237.

(19) Schubert, H.; Petzow, G. In Science and Technol ogy of Zirconia III: Sömiya, S., Yamamoto, N., Yanagida, H., Eds.; American Ceramic Society: Westerville, OH, 1986; p 21.

(20) Sato, T.; Ohtaki, S.; Endo, T.; Schimada, M. In Science and Technol ogy of Zirconia III; Sömiya, S., Yamamoto, N., Yanagida, H., Eds.; American Ceramic Society: Westerville, OH, 1986; $p$ 29.

(21) Winnubst, A. J . A.; Burggraaf, A. J . In Science and Technology of Zirconia III; Sömiya, S., Yamamoto, N., Yanagida, H., Eds.; American Ceramic Society: Westerville, OH, 1986; p 39.

(22) Iio, S.; Watanabe, M.; Kuroda, K.; Saka, H.; Imura, T. In Science and Technology of Zirconia III: Sömiya, S., Yamamoto, N., Yanagida, H., Eds.; American Ceramic Society: Westerville, $\mathrm{OH}$, 1986; p 49.

(23) Hecht, N. L.; J ang, S. D.; McCullum, D. E. In Science and Technol ogy of Zirconia III; Sömiya, S., Y Yamamoto, N., Yanagida, H., Eds.; American Ceramic Society: Westerville, OH, 1986; $p$ 133.

(24) Sato, T.; Ohtaki, S.; Endo, T.; Schimada, M. In Science and Technol ogy of Zirconia III; Sömiya, S., Yamamoto, N., Yanagida, H., Eds.; American Ceramic Society: Westerville, OH, 1986; $p$ 501.

(25) Arai, T.: Yamamoto, T.; Tsuji, K. In Science and Technol ogy of Zirconia III; Sömiya, S., Yamamoto, N., Yanagida, H., Eds.; American Ceramic Society: Westerville, OH, 1986; p 517.

(26) Yoshimura, M.; Hiuga, T.; Sömiya, S. J . Am. Ceram. Soc. 1986 69, 583.

(27) Yoshimura, M.; Noma, T.; Kawabata, K.; Sömiya, S. J . Mater Sci. Lett. 1987, 6, 465 .

(28) Lu, H. Y.; Chen, S. Y. J . Am. Ceram. Soc. 1987, 70, 537.

(29) Yoshimura, M. Am. Ceram. Soc. Bull. 1988, 67, 1950.

(30) Lepistö, T. T.; Mäntylä, T. A. Ceram. Eng. Sci. Proc. 1989, 10, 658.

(31) Chen, S. Y.; Lu, H. Y. J . Mater. Sci. 1989, 24, 453.

(32) Whalen, P. J .; Reidinger, F.; Antrim, R. F. J . Am. Ceram. Soc 1989, 72, 319

(33) Sato, T.; Endo, T.; Shimada, M.; Mitsudome, T.; Otabe, N. J. Mater. Sci. 1991, 26, 1346.

(34) Swab, J.J. J . Mater. Sci. 1991, 26, 6706.

(35) Tsubakino, H.; Nozato, R.; Hamamoto, M. J . Am. Ceram. Soc. 1991, 74, 440

(36) Hernandez, M. T.; J urado, J . R.; Duran, P. J . Am. Ceram. Soc. 1991, 74, 1254. 
(37) J ue, J . F.; Chen, J .; Virkar, A. V. J . Am. Ceram. Soc. 1991, 74, 1811.

(38) Sakka, Y. J. Mater. Sci. Lett. $1992,11,18$

(39) Hirano, M. Br. Ceram. Trans. J. 1992, 91, 139.

(40) Kountouros, P.; Petzow, G. In Scienceand Technol ogy of Zirconia V; Badwal, S. P. S., Bannister, M. J ., Hannink, R. H. J ., Eds.; Technomic: Lancaster, 1993; p 30.

(41) Drennan, J .; Hartshorn, A. J .; Thompson, S. W. In Science and Technol ogy of Zirconia V; Badwal, S. P. S., Bannister, M. J ., Hannink, R. H. J., Eds.; Technomic: Lancaster, 1993; p 144.

(42) Hughes, A. E.; Ciacchi, F. T.; Badwal, S. P. S. In Science and Technology of Zirconia V; Badwal, S. P. S., Bannister, M. J ., Hannink, R. H. J., Eds.; Technomic: Lancaster, 1993; p 152.

(43) Kruse, O.; Carstanjen, H. D.; Kountouros, P. W.; Schubert, H. Petzow, G. In Science and Technol ogy of Zirconia V; Badwal, S. P. S., Bannister, M. J., Hannink, R. H. J ., Eds.; Technomic Lancaster, 1993; p 163.

(44) Azzoni, C. B.; Paleari, A.; Scardina, F.; Krajewski, A.; Ravaglioli, A.; Meschke, F. J . Mater. Sci. 1993, 28, 3951.

(45) Kim, Y. S.; J ung, C. H.; Park, J . Y. J . Nudl. Mater. 1994, 209, 326.

(46) Hughes, A. E.; Ciacchi, F. T.; Badwal, S. P. S. J . Mater. Chem. 1994, 4, 257.

(47) Srikanth, V.; Subbarao, E. C. J . Mater. Sci. 1994, 29, 3363.

(48) Zhu, H. Y. J. Mater. Sci. 1994, 29, 4351.

(49) Lee, J. K.; Kim, H. Ceram. Int. 1994, 20, 413.

(50) Govila, R. K. J. Mater. Sci. 1995, 30, 2656

(51) Lawson, S. J . Eur. Ceram. Soc. 1995, 15, 485.

(52) Basu, D.; Dasgupta, A.; Sinha, M. K.; Sartar, B. K. Ceram. Int. 1995, 21, 277.

(53) Lofthouse, G. C.; Lawson, S.; Gill, C. Key Eng. Mater. 1995, 99 100, 265.

(54) Hughes, A. E.; St J ohn, H.; Kountouros, P.; Schubert, H. J . Eur. Ceram. Soc. 1995, 15, 1125.

(55) Yashima, M.; Nagatome, T.; Noma, T.; I shizawa, N.; Suzuki, Y.; Yoshimura, M. J. Am. Ceram. Soc. 1995, 78, 2229.

(56) Boutz, M. M. R.; Winnubst, A. J. A.; van Langerak, B.; Olde Scholtenhuis, R. J . M.; Kreuwel, K.; Burggraaf, A. J . J . Mater. Sci. 1995, 30, 1854

(57) Kim, D. J .; J ung, H. J .; Cho, D. H. Solid State Ionics 1995, 80 , 67.

(58) Basu, D.; Dasgupta, A.; Basu, M. K.; Sartar, B. K.J . Eur. Ceram. Soc. 1996, 16, 613.

(59) Tan, H. C.; Gill, C.; Lawson, S. Key Eng. Mater. 1996, 113, 199.

(60) Lawson, S.; Gill, C.; Dransfield, G. P. Key Eng. Mater. 1996, 113, 207.

(61) Li, J . F.; Watanabe, R. Mater. Trans., J IM 1996, 37, 1171.

(62) Li, J . F.; Watanabe, R.; Zhang, B. P.; Asami, K.; Hashimoto, K. . Am. Ceram. Soc. 1996, 79, 3109

(63) Li, J . F.; Watanabe, R. J . Mater. Sci. 1997, 32, 1149.

(64) Hirano, M.; Kato, E.J . Ceram. Soc. J pn. 1997, 105, 37.

(65) Kim, D. J . J . Eur. Ceram. Soc. 1997, 17, 897.

(66) Chung, T. J .; Song, H.; Kim, G. H.; Kim, D. Y. J . Am. Ceram. Soc. 1997, 80, 2607

(67) Bowen, C.; Ramesh, S.; Gill, C.; Lawson, S. J . Mater. Sci. 1998 33, 5103

(68) J ansen, S. R.; Winnubst, A. J . A.; He, Y.J .; Verweij, H.; van der Varst, P. G. T.; de With, G. J . Eur. Ceram. Soc. 1998, 18, 557.

(69) Kim, D. J .; J ung, H. J .; J ang, J . W.; Lee, H. L. J. Am. Ceram. Soc. 1998, 81, 2309.

(70) Merle-Mejean, T.; Barberis, P.; Othmane, S. B.; Nardou, F.; Quintard, P. E. J . Eur. Ceram. Soc. 1998, 18, 1579.

(71) Li, J . F.; Watanabe, R. J . Am. Ceram. Soc. 1998, 81, 2687.

(72) Guo, X. Solid State I onics 1998, 112, 113.

(73) Guo, X. J. Phys. Chem. Solids 1999, 60, 539.

(74) Kim, Y. S.; Kwon, S. C. J . Nucl. Mater. 1999, 270, 165.

(75) Lee, D. Y.; Kim, D. J .; J ang, J . W.; Choi, D. W.; Lee, S. J . Mater. Lett. 1999, 39, 221.

(76) Belous, A. G.; Makarenko, A. N.; Pashkova, E. V.; Khomenko, B. S. I norg. Mater. 1999, 35, 1147.

(77) Wada, S.; Yokoyama, K. J . Ceram. Soc. J pn. 1999, 107, 92.

(78) Ohmichi, N.; Kamioka, K.; Ueda, K.; Matsui, K.; Ohgai, M. J . Ceram. Soc. J pn. 1999, 107, 128.

(79) Ohmichi, N.; Kamioka, K.; Ueda, K.; Matsui, K.; Ohgai, M. J . Ceram. Soc. J pn. 1999, 107, 820.

(80) Hirano, M.; Kato, E. J. Mater. Sci. 1999, 34, 1399.
(81) Ramesh, S.; Gill, C.; Lawson, S. J . Mater. Sci. 1999, 34, 5457.

(82) Koh, Y. H.; Kong, Y. M.; Kim, S.; Kim, H. E. J . Am. Ceram. Soc. 1999, 82, 1456

(83) Ho, F. Y.; Wei, W. C. J . J . Am. Ceram. Soc. 1999, 82, 1614.

(84) Chevalier, J .; Cales, B.; Drouin, J . M. J . Am. Ceram. Soc. 1999, 82,2150

(85) Zhu, W. Z.; Zhang, X. B. Scr. Mater. 1999, 40, 1229.

(86) Guo, X. Adv. Eng. Mater. 2000, 2, 604.

(87) Yasuda, K.; Takeda, H. J. Mater. Sci. 2000, 35, 4379.

(88) Djurado, E.; Dessemond, L.; Roux, C. Solid State I onics 2000 $136-137,1249$

(89) Guo, X. Phys. Status Solidi A 2000, 177, 191.

(90) Guo, X. J. Mater. Sci. 2001, 36, 3737.

(91) Shojai, F.; Mäntylä, T. A. J. Eur. Ceram. Soc. 2001, 21, 37.

(92) Shojai, F.; Mäntylä, T. A. Ceram. Int. 2001, 27, 299.

(93) Li, J. G.; Žhang, L. M.; Shen, Q.; Hashida, T. Mater. Sci. Eng. A 2001, 297, 26

(94) Cai, S.; Yuan, Q. M.; Meng, J . H.; Yang, Z. F.; Chen, Y. J . Eur. Ceram. Soc. 2001, 21, 2911.

(95) Grant, K. L.; Rawlings, R. D.; Sweeney, R. J . Mater. Sci.-Mater. Med. 2001, 12, 557

(96) Yasuda, K.; Goto, Y.; Takeda, H. J . Am. Ceram. Soc. 2001, 84, 1037.

(97) Oskarsson, M.; Ahl berg, E.; Pettersson, K.J . Nucl. Mater. 2001, 295,126

(98) Lance, M. J .; Vogel, E. M.; Reith, L. A.; Cannon, W. R. J . Am Ceram. Soc. 2001, 84, 2731.

(99) Guo, R.; Guo, D.; Zhao, D.; Yang, Z.; Chen, Y. Mater. Lett. 2002, 56,1014

(100) Kanellopoulos, P.; Gill, C. J . Mater. Sci. 2002, 37, 5075.

(101) Lin, J. D.; Duh, J. G.; Lo, C. L. Mater. Chem. Phys. 2002, 77, 808.

(102) Munoz-Saldana, J .; Balmori-Ramirez, H.; J aramillo-Vigueras, D.; I ga, T.; Schneider, G. A. J . Mater. Res. 2003, 18, 2415.

(103) Menezes, C. A. B.; Lazar, D. R. R.; Ussui, V.; Lima, N. B.; Paschoal, J. O. A. Mater. Sci. Forum 2003, 416, 573.

(104) Roebben, G.; Basu, B.; Vleugels, J .; van der Biest, O. J . Eur. Ceram. Soc. 2003, 23, 481

(105) Zhao, Z. B.; Liu, C.; Northwood, D. O. Key Eng. Mater. 2003 $233-236,655$

(106) Kim, D. J .; Lee, D. Y.; Han, J. S. Key Eng. Mater. 2003, 240242,831

(107) Guo, X.; He, J . Acta Mater. 2003, 51, 5123.

(108) Boulc'h, F.; Dessemond, L.; Djurado, E.J . Eur. Ceram. Soc. 2004 24,1181

(109) Guo, X.; Schober, T. J . Am. Ceram. Soc. 2004, 87, 746.

(110) Djurado, E.; Boulc'h, F.; Dessemond, L.; Rosman, N.; Mermoux, M. J . Electrochem. Soc. 2004, 151, A774.

(111) Livage, J .; Doi, K.; Mazieres, C. J . Am. Ceram. Soc. 1968, 51 349.

(112) Fabris, St.; Paxton, A. T.; Finnis, M. W. Acta Mater. 2002, 50 , 5171.

(113) Kreuer, K. D. Chem. Mater, 1996, 8, 610.

(114) Kreuer, K. D. Solid State I onics 1999, 125, 285.

(115) Kreuer, K. D.; Adams, St.; Münch, W.; Fuchs, A.; Klock, U.; Maier, J. Solid State I onics 2001, 145, 295.

(116) Redfern, S. E.; Grimes, R. W.; Rawlings, R. D. J . Mater. Chem. 2001, 11, 449 .

(117) Simpson, L. A.; Carter, R. E. J . Am. Ceram. Soc. 1966, 49, 139

(118) Norby, T. In Advances in Zirconia Science and Technology; Meriani, S., Palmonari, C., Eds.; Elsevier: New York, 1989; p 209.

(119) Raz, S.; Sasaki, K.; Maier, J .; Riess, I. Solid State I onics 2001 $143,181$.

(120) Guo, X. Solid State Ionics 1995, 81, 235.

(121) Guo, X.; Maier, J . J . Electrochem. Soc. 2001, 148, E 121.

(122) Guo, X.; Sigle, W.; Fleig, J .; Maier, J . Solid State I onics 2002 154-155, 555

(123) Guo, X. Comput. Mater. Sci. 2001, 20, 168

(124) Guo, X.; Zhang, Z. Acta Mater. 2003, 51, 2539

(125) Etsell, T. H.; Flengas, S. N. Chem. Rev. 1970, 70, 339

(126) Mackrodt, W. C.; Woodrow, P. M. J . Am. Ceram. Soc. 1986, 69 277.

(127) Behrens, G.; Heuer, A. H. J . Am. Ceram. Soc. 1996, 79, 895. CM040167H 